\title{
La gramática en la diacronía: La evolución de las perífrasis verbales modales en español
}

Garachana-Camarero, M. (Ed.) (2017). La gramática en la diacronía: La evolución de las perífrasis verbales modales en español (Colec. Lingüística Iberoamericana $n^{\circ}$ 69, 400 pp., ISBN 978- 84-1692-257-4). Madrid: Iberoamericana Vervuert.

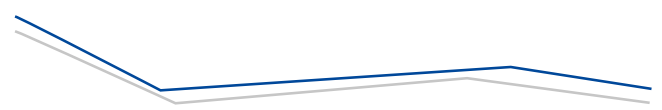

\section{Cristina Eslava-Heredia*®}

Eslava-Heredia, C. (2020). La gramática en la diacronía: La evolución de las perífrasis verbales modales en español [Reseña de libro]. Investigación y Ciencia de la Universidad Autónoma de Aguascalientes, 28(81), 96-97.

El estudio de las perífrasis verbales modales del español ha sido un campo poco abordado desde una perspectiva histórica, y mucho menos se conocen trabajos que reflejen un estudio amplio y concentrado de estas estructuras. Los trabajos conocidos hasta ahora casi siempre son de corte muy general o didácticos o suelen tratar una estructura particular por separado.

El libro que se reseña aquí tiene la virtud de ser un compendio de trabajos que armonizan en el estudio diacrónico de las perífrasis modales más representativas de la lengua española. Se trata de una obra que presenta consistencia teórica y metodológica, ya que los autores participantes comparten los mismos marcos teóricos (teoría de la gramaticalización y teoría de las construcciones), además de compartir los mismos métodos de tratamiento documental y rigor estadístico que permiten apoyar sus conclusiones con evidencia empírica significativa.

La obra ofrece una introducción que contextuliza el lugar que toma esta monografía dentro del estudio de las perífrasis en español, además de ocho capítulos escritos por distintos investigadores. Los dos primeros capítulos dedican sus páginas en presentar las herramientas teóricas y aspectos metodológicos para el estudio de las perífrasis verbales. El resto de los trabajos se ordenan según la frecuencia de uso de cada una de las

\footnotetext{
* Departamento de Letras, Centro de las Artes y la Cultura, Universidad Autónoma de Aguascalientes. Av. Universidad 940, Ciudad Universitaria, C. P. 20131, Aguascalientes, Aguascalientes, México. Correo electrónico: cristina.eslava@edu.vaa.mx ORCID: http://orcid. org/0000-0003-0170-4838

$\otimes \quad$ Autora para correspondencia
}

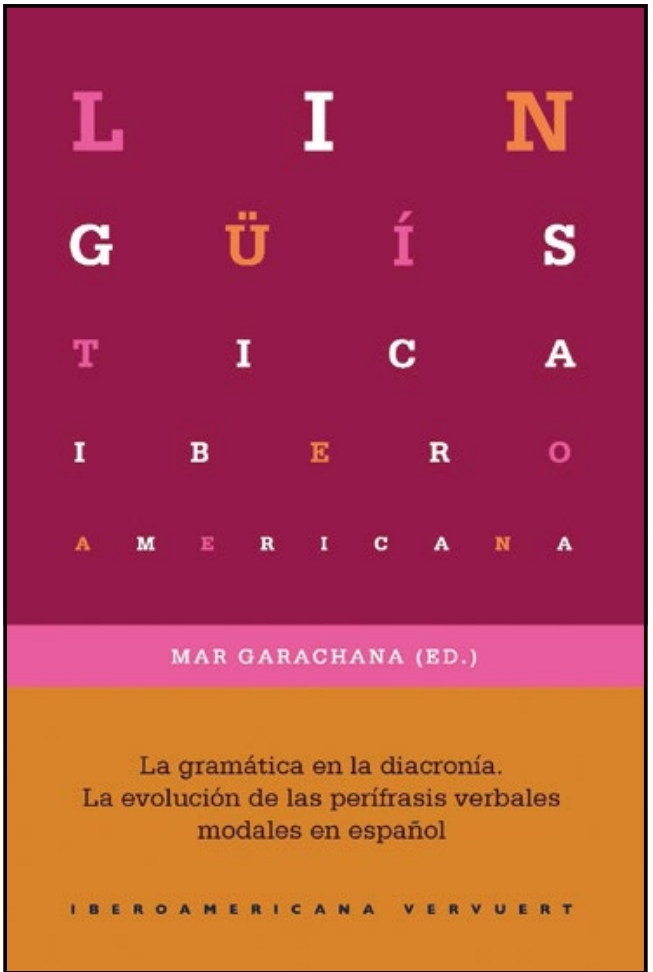

Portada del libro La gramática en la diacronía: La evolución de las perífrasis verbales modales en español.

perífrasis estudiadas. A continuación se resume el contenido de cada capítulo:

El capítulo primero: "Los límites de una categoría híbrida. Las perífrasis verbales" (p. 35), escrito por Mar Garachana-Camarero, está dedicado a la noción de perífrasis verbal y a las dificultades de establecer una nómina básica de las perífasis en español.

El capítulo segundo: "Modalidad, cambio lingüístico y construcciones perifrásticas" (p. 81), elaborado por Maria Josep Jarque, está dedicado 
al concepto de modalidad con el fin de trazar las posibles rutas diacrónicas que sigue la modalidad en los procesos de conformación de las perífrasis modales.

Esther Artigas y Laura Cabré elaboran el tercer capítulo: "Saber no es 'soler' en latín. A propósito del origen de la perífrasis saber + infinitivo" (p. 117). Se trata de un estudio que se apoya en documentación tanto latina como hispánica y cuyos hallazgos les permite concluir a las autoras que el valor aspectual de la perífrasis saber + infinitivo no tiene su origen en la lengua latina.

El cuarto capítulo: "La historia de las perífrasis deber / deber de + infinitivo: Variación, norma y géneros textuales" (p. 147) de Malte Rosemeyer estudia la historia de dos perífrasis que expresan valores deónticos y epistémicos. El autor ubica el origen de la perífrasis deber +infinitivo en el latín, mientras que la forma con preposición deber de + infinitivo surge durante la época medieval. El capítulo describe los diferentes momentos de competencia entre ambas perífrasis en la historia del español. El autor propone que la inclusión de la preposicón de podría estar dada por influencia de otras perífrasis modales con la misma preposición.

En el quinto capítulo: "Las perífrasis con el verbo haber + infinitivo. De los valores expresados por estas formas" (p. 197), Axel Hernández Díaz muestra que el significado original de haber + infintivo no es de carácter deóntico tal como se afirma en la tradición, sino que existen ciertos contextos que pudieron favorecer un sentido de baja carga deóntica, contextos más próximos a los valores epistémicos y de futuridad.

Mar Garachana-Camarero, en el capítulo 6: "Perífrasis formadas en torno a tener en español: Ser tenudo/tenido $\varnothing / a / d e+$ infinitivo, tener a/de + infinitivo, tener que + infinitivo" (p. 229), elabora su trabajo alrededor de aquellas perífrasis formadas con el verbo auxilar tener. Plantea una dinámica de entrada y salida de estas estructuras en la lengua sin que esto sugiera que haya existido una sustitución de unas formas por otras. La estructura más antigua Ser tenudo/tenido $\varnothing / a / d e+$ infinitivo se especializaba en la expresión de una necesidad externa hasta el siglo XV. Por otra parte, la perifrasis tener a/de + infinitivo es una construcción documentada desde el siglo XIII, pero cuya frecuencia de uso vio su mayor pico a finales de la época medieval; su desaparición parece estar fuertemente relacionada con su baja frecuencia, una baja especialización y al hecho de que existían ya otras perífrasis deónticas, como tener que y deber de que podrían ocupar su lugar.

En el capítulo 7: "Parece ser perífrasis: categorización y evolución diacrónica de parecer + infinitivo" (p. 287), Dorien Nieuwenhuijsen dedica el trabajo a demostrar que la estructura de parecer + infinitivo puede ser considerada en la nómina de perifrasis del español. Los datos utilizados le permiten demostrar que la perífrasis no viene del desplazamiento a la izquierda del sujeto de la oración subordinada dependiente de parecer (parece que Suj $\rightarrow$ Suj parece que), sino que pudiera ser una extención que parte de la estructura parecer ser + adjetivo.

Por último, cierra esta monografía el capítulo 8: "¿La obligación por pasiva? Historia y uso de la construcción ser de + infinitivo" (p. 329) elaborado por Álvaro S. Octavio de Toledo y Huerta. En este estudio se muestra que la construcción ser de + infinitivo poseía valores deónticos durante el periodo medieval y renacentista, los cuales posteriormente se pierden ante el avance de otras perífrasis deónticas como haber que + infinitivo.

Considero que se trata de una obra que aporta información valiosa sobre las perífrasis verbales del español. Es una obra que muestra originalidad temática, consistencia teórica y metodológica y rigurosidad estadística. Predigo que será una obra de consulta obligada para futuros estudios sobre las perífrasis verbales en general. 